\title{
Subversive Joy and Positive Reciprocity: A Chestertonian-Girardian Dialogue
}

Duncan Reyburn

University of Pretoria

In his spiritual autobiography Orthodoxy (1908), the highly prolific post-Victorian journalist, philosopher and Anglo-Catholic theologian Gilbert Keith Chesterton (1874-1936), in a particularly strong argument against one brand of Socialism, notes the following:
In the modern ideal conceptions of society there are some desires that are
possibly not attainable: but there are some desires that are not desirable. That all men
should live in equally beautiful houses is a dream that may or may not be attained.
But that all men should live in the same beautiful house is not a dream at all; it is a
nightmare. ${ }^{1}$

This short excerpt does not in any way capture the full trajectory of Chesterton's larger argument at this point in his book, but I quote it here to highlight one incarnation of his understanding both of the structure of mimetic desire and the violent consequences that may arise out of mimetic desire. To begin with, there is the notion that desires for attaining things involve the desire of another. This follows René Girard's discovery, after Shakespeare, of the centrality of "borrowed desire" or "desire by another's eye" to human interactions. ${ }^{2}$ Moreover, there is Chesterton's observation that when this mimetic desire is shared, "nightmare" is inevitable: when many hands covet the same object, the result is bitter rivalry. ${ }^{3}$

The above excerpt's demonstration of Chesterton's own understanding of mimetic desire thus paves the way for the central aim of this article, which is to present an articulation of some of the ways in which Chesterton's philosophy might counterbalance the Girardian accentuation of reciprocal violence. ${ }^{4}$ This aim is achieved via an examination of how Chesterton articulates his understanding of mimetic desire, as well as an exploration of how this is performed in a few examples from his fictional work. I argue that the centrality of joy to Chesterton's work is a helpful means for understanding positive reciprocity, and also introduce a brief discussion of the concept of the "Symbolism of Syntax" that acts as a unique expression of what both Chesterton and Girard are getting at with regard to their conceptions of mimetic desire. ${ }^{5}$ There is a doubleillumination in what follows: By interpreting Chesterton through a Girardian lens, one is able to show both how Girard sheds light on Chesterton and how Chesterton sheds light on Girard.

To begin with, it is clear that Chesterton regards mimesis in its simplest sense as being fundamental to human nature. It is a democratic phenomenon that is involved in issues ranging 
from nations that imitate the policies of other nations, ${ }^{6}$ to fictional characters and "caricatures" being modeled on actual people, ${ }^{7}$ to criminals who emulate the wrong sort of people, ${ }^{8}$ to copying as the means by which such things as clichés, education, fashions and value judgments spread. ${ }^{9}$ Even in this small sampling of examples, Chesterton seems to share Aristotle's basic contention that human beings possess a unique aptitude for imitation. Nevertheless, Chesterton does not regard this mimesis as merely involving surface representation, although such representation remains an important concern. Rather, in his estimation, the core issue with regard to imitation remains the imitation of the desires of others.

Chesterton writes of the imitation of an ideal in a way that is comparable to Girard's notion of mimetic desire. ${ }^{10}$ Chesterton's ideal, which is articulated as a "fixed vision," "form" or "shape", refers to something desired, whether rightly or wrongly, both by individuals and by groups. ${ }^{11}$ An ideal, which Chesterton often equates with "dogma," "doctrine," "intention" or even "motive," acts as the point of connection that both unifies and divides. ${ }^{12}$ It is the axis around which communities form and rotate, as well as the source of conflict among their members.

This ideal, in Chesterton's mind, does not have to be an entirely abstract idea, but can in fact be a person. As an example, he offers Marcus Aurelius as one who may be emulated as an archetypal "monarch and sage." ${ }^{13}$ Thus, Chesterton makes the Ancient Roman emperor the model for the imitation of Stoic ideals. Moreover, he points to St. Francis of Assisi as someone who took the "imitation of Christ" particularly seriously. ${ }^{14}$ Here, then, he reflects the Pauline emphasis on imitating those who imitate Christ; that is, here we find the notion of relying upon a suitable model with regard to reaching a goal. ${ }^{15}$ Chesterton is therefore aware that this imitation of an ideal should not be simplistically reduced to being merely the desire of one person for an object. Rather, he recognizes desire as something mimicked, and also as something that can be for more than an object, as is the case of what Girard calls "metaphysical desire" as a "desire to be" that "brings into being a certain relationship to others and to oneself." 16 On St. Francis of Assisi, Chesterton also remarks that "St. Francis is a most sublime approximation to his Master, and, even in being an intermediary and a reflection, is a splendid and yet a merciful Mirror of Christ."17 Here, imitation is again tied to mediation, and the 'thing' that is mediated is something sublime and not just material. This means that, to refer to an example supplied by Chesterton, one man may tell a different story "from another man" even while "[one] may tell it from the same motive as the other man." 18 We can see in all of this, then, that there are two dimensions to Chesterton's view of the imitation of an ideal, the latter of which takes priority in his work: a visible dimension and an invisible dimension. 
This imitated ideal can involve both the simplicity of a single ideal, as well as the complexity of a dramatic network of ideals, intentions and motivations. Therefore it becomes possible to imitate one ideal out of that complex network of ideals without ever properly catching onto the primary ideal that unifies all other ideals. With regard to the imitation of Christ, for instance, Chesterton notes that people may place a network of ideals in a kind of false hierarchy, such that leads "the Christian Scientist [to be] happy with [Christ only] as a spiritual healer and the Christian Socialist [to be] happy with him [only] as a social reformer, so satisfied that they do not expect him to be anything else." 19 Nevertheless, Chesterton argues on this point that "[t]here must surely have been something not only mysterious but many-sided about Christ if so many Christs can be carved out of him." 20 What he is intimating here is that a model may mislead others by reinterpreting the 'object' of desire, which in this case is Christ, in his own image. Moreover, it is clear here that, for Chesterton as for Girard, the free will of the subject in choosing the precise way in which he will follow his primary model remains paramount even if he is not absolutely conscious of his freedom. ${ }^{21}$

By considering the complex interrelationship of ideals, Chesterton's stance echoes James Alison's suggestion that a theory of mimetic desire is more like the "Little Way" of St. Thérèse of Lisieux than "yet another totalitarian thought package."22 It should be taken as a small window that allows for an expansive view, rather than as a box that restricts one's perception. Even so, it would seem at first that Chesterton, in his own anthropological theory, may be offering a way of thinking about mimetic desire that is somewhat opposed to the Girardian perspective. In particular, it appears that Chesterton's views on mythology differ somewhat from the Girardian reading when he contends that to insist that all myths contain similar elements is a "monomania of plagiarism." ${ }^{23}$ On this specific point he is being critical of Sir James George Frazer's notion of "the Golden Bough," which (to speak very broadly) unifies mythology around the relationships between violence, sacrifice and an array of taboos. ${ }^{24}$ However, Chesterton's critique also extends to other ways of reading mythology:

The true origin of all the myths has been discovered much too often. There are too many keys to mythology, as there are too many cryptograms in Shakespeare. Everything is phallic; everything is totemistic; everything is seed-time and harvest; everything is ghosts and grave-offerings; everything is the golden bough of sacrifice; everything is the sun and moon; everything is everything. ${ }^{25}$

Here, Chesterton is somewhat dismissive of any attempt to reduce my thology to a single explanation. And yet, his own anthropology assumes that mythology is primarily a search for God and truth via the imagination. ${ }^{26}$ He therefore concedes that mythology is essentially concerned with a shared desire that he deems fundamental to human nature, namely the desire to 
worship. After all, he writes, "man found it natural to worship; even natural to worship unnatural things. The posture of the idol might be stiff and strange; but the gesture of the worshipper was generous and beautiful. He not only felt freer when he bent; he actually felt taller when he bowed." 27 It is on this point that any apparent contradiction between Chesterton's and Girard's explications of mythology is dissolved. Both recognize that man has an unalterably "religious nature," which means that he is given either to faith in a God or some form of idolatry, with no third possibility open to him. ${ }^{28}$ This inbuilt facet of human nature leaves the necessity of mimetic desire wide open, since it suggests that human beings will always be in the process of seeking something to answer to this inherent inner call. Mimetic desire, which seeks communion and participation with, as well as the adoration and emulation of another, is deemed interwoven into our very being.

The implication of this, for both Chesterton and Girard, is that desire arises out of a sense of incompleteness. For Girard in particular, mimetic desire tends to be adjusted towards imitating the other's fulfillment and originality; it is often, although not always, a self-deception that masks one's insufficiency. ${ }^{29}$ To be clear, this incompleteness or insufficiency is not to be confused with Martin Heidegger's articulations of "ontological impoverishment" or Jean-Paul Sartre's “concept of the lack of being." ${ }^{30}$ Both Chesterton and Girard have a sense that being's incompleteness is God-ordained; it is the result of being, as Chesterton remarks, "secondary and dependent." 31 Chesterton stresses this when he writes that the incompleteness in the reality of things "can only be explained as part of something that is complete. It is God." ${ }^{32}$ Lack, as the fuel of worship and mimetic desire, does not make an ontology of violence necessary at all. It is the simply result of being part of the created rather than the uncreated order, and is therefore both originally and teleologically bound to completeness. Nevertheless, when a desire for God is supplanted by a desire for an idol, rivalry and reciprocal violence become inevitable. Apart from God, the self becomes unstable, restless, fragmented and given to the whims envy and pride. These are the marks of the Fall — the direct result of the human subject's seeking after "substitute gods." 33 The inference of this is clear: "humans after the Fall must refocus their desire on God in order to avoid worldly seduction and to escape their violent nature." ${ }^{34}$ Man's right relationship with God, others and the created order needs to be restored, and this means retrieving his position as a creaturely image of the Creator God.

Pride is at the center of both Chesterton's and Girard's conceptions of the Fall. Therefore, their pronouncements on humility, as pride's obvious converse, become crucial for a more precise vision of what it might mean for man to reclaim this creaturely position. Girard argues that "[n] ovelistic genius begins with the collapse of the 'autonomous' self." 35 It is therefore clear that humility allows another way of considering the "conversionary, nonviolent imitation of divine 
love" that Girard takes to be paramount to undermining mimetic violence. ${ }^{36} \mathrm{He}$ indicates "[r] ecapturing the past" as a primary key to humility, because it reveals the fact that the self is not the originator of its own opinions or even its own sense of identity. The "death of pride" leads to the "birth of humility and thus of truth." ${ }^{37}$ Chesterton also connects humility to truth, but he takes his exploration of humility beyond Girard's, thus providing some further illumination on how positive reciprocity may be fueled.

Chesterton defines humility as "the luxurious art of reducing ourselves to a point, not to a small thing or even a large one, but to a thing with no size at all." ${ }^{38}$ Humility, in his view, is consistent with the great reversals of the New Testament. ${ }^{39}$ It concerns giving up the very self that seeks to imitate the desires of the other, as well as the recognition that the self is often merely an illusory construct determined by the gaze of the other. The purpose of this great reversal is the recognition of the self's relation to and dependence upon that which is beyond the self. It undermines the lie that leads to the Fall, namely that God is a rival, by recognizing him as the true Source and Ground of one's very being, as well as the Source of the being of any other potential rivals. Nevertheless, Chesterton is explicit in contending that humility is only achievable under conditions of security, implying the primacy of redemption. ${ }^{40}$ Humility, like redemption and revelation, is not just something willed by the individual, but is an event that happens to him.

Chesterton argues that humility "follows with the precision of clockwork every one of the great joys of life. No one, for example, was ever in love without indulging in a positive debauch of humility." ${ }^{41}$ Furthermore, he writes that humility is enjoyed the moment that "hero-worship" is attained. ${ }^{42}$ In this, he refers to a model — a hero — but in the very particular context of enjoyment, which can only exist in its pure form prior to the model becoming a rival. Elsewhere he notes that "[i]t is impossible without humility to enjoy anything — even pride." 43 While enjoyment may be somewhat transitory, it remains a sign or perhaps even a sacrament of something more permanent that Chesterton deems to be at the heart of being, namely joy. He contends that man is more himself, more human and therefore more in tune with reality, "when joy is the fundamental thing in him," rather than any other fleeting emotion: "Melancholy should be an innocent interlude, a tender and fugitive frame of mind; praise should be the permanent pulsation of the soul. Pessimism is at best an emotional half-holiday; joy is the uproarious labor by which all things live." ${ }^{44}$ Chesterton therefore connects joy with worship as the fundamental impulse of the human subject. In doing so, he does not overlook evil, suffering and violence as obvious problems for life and the intellect, but indicates that these problems are all parasitic distortions of the mystery of joy that forms the gateway to man's right relationship with God. Joy must therefore have an ontological significance since it aligns the creature with "the divine creative act." 45 Joy overflows and thus answers to the lack that is at the heart of mimetic desire. It 
brings the creature into harmony with a pattern of desire that is Trinitarian and self-giving rather than other-consuming. It transforms the metaphysical desire that seeks the being of the other into a deep desire for the other to be. It seeks things to be uniquely themselves, and thus looks for ways to work towards both their completeness and the completeness of the self. When the soul pulsates with praise, the self becomes a generative and celebratory instrument. Chesterton claims that " $[\mathrm{g}]$ ratitude $[$ is $]$ nearly the greatest of all human duties" but acknowledges that it is also "nearly the most difficult." ${ }^{46}$ Still, in his view, generosity is inconceivable without this joyful posture of thanksgiving.

Without joy, the transformation of negative reciprocity into positive reciprocity is impossible to understand. On its own, humility allows for the first part of the great reversal that is expressed in the denial of self; but joy, which for Chesterton is always implied by humility, allows for the second part of this reversal: the restoration of individual selves. It is obvious in Girard's thinking that identification with the victim is important for escaping entrapment in mimetic rivalry, because it allows for the recognition of sameness: our being will always remain secondary and dependant. Nevertheless, Chesterton's attention to joy leads to an equally important part of positive reciprocity, namely the recognition and celebration of difference. It is in this paradox of sameness and difference that love is born: "Love desires personality; therefore love desires division. It is the instinct of Christianity to be glad that God has broken the universe into little pieces, because they are living pieces. It is her instinct to say 'little children love one another' rather than to tell one large person to love himself." 47 The very love that sets things free to be themselves is the same love that pledges allegiance to the other. Chesterton observes that true love is "not blind; that is the last thing it is. Love is bound; and the more it is bound the less it is blind." ${ }^{48}$ It can therefore be contended that Chesterton sets up a relationship between humility, joy and love that allows for a dramatic interplay of similarity and difference, and it is through this interplay that metaphysical desire is transformed to allow for positive reciprocity.

Bearing the above in mind, the question of how Chesterton performs his understanding of mimetic desire in his fictional works remains. To begin with, I examine how he illustrates his views on this subject in his fiction, and, following this, I explore how his philosophy of joy undermines violent reciprocity. Of course, it is impossible in such a small space to cover all of Chesterton's fictional writing. Thus, here I am going to refer only to three select examples, beginning with Chesterton's first Father Brown short story The blue cross (1911) before moving on to a brief discussion of The man who was Thursday (1908) and Manalive (1912). Central to these examples, and arguably to Chesterton's whole literary oeuvre, is the idea that seeing may be deceiving, which is to say that there is always a need to pay closer attention than tends to be our custom. 
The blue cross tells the story of a French detective named Aristide Valentin, who is in hot pursuit of a highly talented criminal named Flambeau. ${ }^{49}$ Flambeau is noted to have escaped from the police "once by a pair of nail scissors, and once by a house on fire; once by having to pay for an unstamped letter, and once by getting people to look through a telescope at a comet that might destroy the world." ${ }^{50}$ Chesterton's point here is that we are dealing with an imaginative criminal who knows how to get himself out of a jam by any means available. This, quite understandably, makes Valentin quite bitter, as we come to understand when, over a cup of coffee that he is drinking at a hotel, he remarks, "The criminal is the creative artist; the detective only the critic." 51 Immediately after saying this, Valentin takes a sip of his coffee only to discover that he had somehow managed put salt into it instead of sugar. This mistake, he soon realizes, was owed to the fact that there was salt, not sugar, in the sugar-basin. On complaining of this mix-up to the waiter, the waiter first informs him that it is most certainly not the policy of the hotel to switch condiments and then explains that the culprits must have been "those two clergymen" who, he adds, had also "[thrown] soup at the wall" before leaving. ${ }^{52}$

Even if the strange behavior of the clergymen cannot be considered criminal in any strict sense, it is suspicious enough to lead Valentin to forget his search for Flambeau and pursue them instead. In the process, he finds himself following a whole string of further oddities, just as if he were being lead by a trail of breadcrumbs. At a market, he discovers nuts that have been marked as oranges and is told by the storeowner that the culprits are "two clergymen, one tall and the other short." ${ }^{53}$ At the very same market, one of the clergymen had also overturned the apple basket, leaving them to "roll ... all over the street." ${ }^{4}$ Valentin then passes a constable who admits to seeing which way the clergymen had gone, and also that he is certain that one of them was clearly drunk. ${ }^{55}$ Later, Valentin meets a man at a restaurant, who tells him that he had indeed served the two priests. The man then explains that while he billed them for 4 shillings, one of the priests insisted on paying him 14 shillings. The priest in question is recorded to have apologized for confusing the accounts, but then said that "it'll pay for the window ... [that] I'm going to break." Thereafter, true to his word, he proceeded to break a window of the restaurant. ${ }^{56} \mathrm{On}$ and on it goes: Valentin keeps on following where the priests have left strange, even disconcerting evidence of their whereabouts. The story seems to reveal two priests who do not seem to be behaving at all like priests. This is to say that at this point in the story they seem unified in their mischief, but are obviously different from normal clergymen.

Eventually, Valentin catches up with the two priests, who are sitting on a park bench engaged in a bit of "metaphysical gossip." 57 While hiding behind a tree, he overhears the taller priest say to the shorter one: "Just hand over that sapphire cross of yours, won't you? We're all alone here, 
and I could pull you to pieces like a straw doll." ${ }^{58}$ After this, the taller priest then admits to the shorter one - a priest named Father Brown - that he is in fact the criminal Flambeau, the very same man that Valentin has been after. It is all of this and more that allows Valentin to step out of hiding and, with the aid of two other policemen, arrest the criminal. ${ }^{59}$ The point that Chesterton makes through this story is significant: Flambeau tries to imitate Father Brown, but fails to imitate his real desire. That is, he imitates the surface but not the substance, and thus is unable to outwit the plump little priest. In Girardian terms, it is the failure of Flambeau that exposes the "romantic lie" that assumes that we are the conscious, deliberate and autonomous authors of our own desires. Father Brown, on the other hand, in small, calculated measures, starts to deliberately and subversively reflect the inward desires of Flambeau by unsettling the world around him. With his own priestly ideals perfectly in tact, he starts to act as a mirror to expose the inward motivations of the criminal that he has always known Flambeau to be, and by doing this he alerts Valentin to the villain's whereabouts and intentions. Surprisingly, it was the usually well-behaved priest who had been behaving badly in order to ensure that the truly badly behaved priest, who was now pretending on the surface to behave fairly well, would be caught. In addition to this somewhat convoluted running commentary on mimetic desire, we also find the seeds of mimetic violence: Flambeau shares Father Brown's desire for the blue cross, but because this is not the only desire at play in the larger context of the story, conflict is ultimately averted.

Chesterton makes two primary points through this story that act as the foundation for all of his Father Brown stories. The first is this: The ideal that Father Brown seeks, by being good, is in fact rational. In a conversation early on in the story, Flambeau attacks reason in order to convince Father Brown of his sincere faith, but through this gesture inadvertently convinces Father Brown of his lack of faith. Father Brown says that to "attack reason" is "bad theology." The second point regards the innocence of Father Brown. How is it that a "celibate simpleton" would have such an excellent understanding of the criminal mind? ${ }^{60}$ To answer this question, Father Brown asks Flambeau: "Has it never struck you that a man who does next to nothing but hear men's real sins is not likely to be wholly unaware of human evil?" ${ }^{\prime 1}$ The priest's patient and obedient humility has allowed him to gain insights that he otherwise would have missed. It is his very innocence of evil, coupled with his deep knowledge of the human psyche, that leads Father Brown to understand the inner life of Flambeau in a way that even Flambeau cannot. Thus, Chesterton notes that the imitated ideal — Father Brown's imitation of Christ that allows him to be a model to others — is the means by which the failed imitation — Flambeau's attempted imitation of Father Brown — is exposed. In this story, it becomes clear that the 'real' or 'authentic' self is understood through its imitation of desire. 
What this story demonstrates, among other things, is this: What matters to Chesterton is the fundamentally invisible nature of the ideal. The invisible ideal is like a seed that hides underground, but which is responsible for the life of the tree that is visible above the ground. ${ }^{62}$ Chesterton writes that " $[\mathrm{i}] \mathrm{n}$ the presence of God, we must remember what is invisible, even in the sense of what is merely intellectual; the abstractions and the absolute laws of thought; the love of truth, and the respect for right reason and honourable logic in things, which God himself has respected." ${ }^{3} \mathrm{He}$ uses the symbol of a trees tumbling in the wind as being "typical of the visible world moving under the violence of the invisible" and explains elsewhere that "the first facts are never material facts. The invisible always comes before the visible, the immaterial before the material, even in our everyday experience." 64

This idea is particularly reflected in Chesterton's novel The man who was Thursday, which acts as the second example of how Chesterton demonstrates mimetic desire in his fiction. There, Chesterton proposes the notion of the "philosophical policemen" whose work

\footnotetext{
is at once bolder and more subtle than that of the ordinary detective. The ordinary detective goes to pot-houses to arrest thieves; we go to artistic tea-parties to detect pessimists, The ordinary detective discovers from a ledger or a diary that a crime has been committed. We discover from a book of sonnets that a crime will be committed. We have to trace the origin of those dreadful thoughts that drive men on at last to intellectual fanaticism and intellectual crime. ${ }^{65}$
}

This passage reflects the very idea that sustains the character of Father Brown, even while it is being used in a different context. Chesterton insists upon delving into the root of crimes, which is found at the heart of human nature, rather than simply working with detecting where crimes have already been committed. The man who was Thursday therefore tells the story of a Scotland Yard detective named Gabriel Syme who infiltrates a collective of anarchists called the Central Anarchist Council, each of whose members bears the name of a day of the week. As the story progresses, Syme, who has taken on the name Thursday, begins to discover, one at a time, that each member of the Council is in fact an under-cover policeman like himself. It is never explicitly stated, but it is implied that the very existence of the Council is owed to the fact that most of its members align themselves with order rather than chaos; that is, its existence is contingent upon a lawful system. Ironically, then, the Council's aim, which is to spread disorder, is undermined by its very existence. Still, the fact that the entire plot of Chesterton's novel revolves around this interplay between the hidden and the revealed is ultimately elucidated through Gabriel Syme, who exclaims towards the end of the novel: "Shall I tell you the secret of the whole world? It is that we have only known the back of the world. We see everything from behind, and it looks 
brutal. That is not a tree, but the back of a tree. That is not a cloud, but the back of a cloud. Cannot you see that everything is stooping and hiding a face?"66

In Chesterton's estimation, the truth of the world is not as obvious as we would have it be. The imitated ideal itself is always hidden, and its hiddenness leads many to believe the romantic lie. What Chesterton points out in The man who was Thursday, however, is that we are not as conscious of our ideals as we might hope to be. In some ways, this novel is similar in its dealings with imitated ideals to the treatment in The blue cross. Nevertheless, it exposes a dimension to mimetic desire that is a constant theme in Chesterton's writings: the inner motivations and desires of people are very difficult to discern, as Syme soon discovers. In fact, part of the difficulty of examining desires is the fact that individuals are sometimes even unaware of their own desires. For this reason, often the only way to discover and discern motivation is to look at how they are revealed in the syntax of speech and action. Thus, in Chesterton's estimation, part of the process of examining desires involves examining the primary mediator of desires, which is language itself. To examine mimetic desire hermeneutically, one needs to recognize that we are born into and shaped by a multifaceted arrangement of interwoven signs and symbols. This is to say that those ideals that are imitated are communicated via language.

Language itself is one model according to which we orientate our desires. This is why Chesterton insists that his primary goal in a great portion of his writings is to "deal with the use and abuse of logic; the use and abuse of language," as well as the "grammar" — both in theory and in practice — of belief and unbelief. ${ }^{67}$ Our desires, including those desires that we hide from ourselves, will somehow be present in the way we communicate. Chesterton introduces his idea of the "Symbolism of Syntax" to explain "the way in which the mere construction of a sentence suggests presumptions or prejudices, apart from anything named or defined." ${ }^{68}$ The idea, put differently, is simply that what is obvious to us may in fact be hiding the face of its true nature. One example would be the sentence 'Everything is meaningless', which in its content seems to present a vehement nihilism, but in its syntax argues for a world full of meaning. The syntax exposes the truth that is being articulated better than the content. Another example would be that of the romantic lie, which in syntax proclaims its dependence upon borrowed words, which are in turn implying borrowed ideals. Flambeau may look like a priest and may even succeed in part at convincing others that he is a priest, but the faulty syntax of his own desires exposes his deceit. The Central Anarchist Council mentioned above also reflects this idea of the symbolism of syntax: The content of the Council is disorder, but its very construction mimics and therefore points to the order of things. 
Chesterton's notion of the symbolism of syntax indicates his hope to expose any "unconscious dogma" — that is, any ideal that is held without being properly recognized for what it is ${ }^{69} \mathrm{He}$ writes that there are "two things, and only two things, for the human mind, a dogma [or doctrine] and a prejudice." 70 He explains that a dogma is a "definite point" — that is, a clear ideal that we are highly aware of — while a "prejudice is a direction" — that is, an unconscious dogma or hidden ideal. ${ }^{71}$ Whether one is clear about the goal without being clear about the motive, or uncertain of the goal even while being certain of the motive, what always remains true is this: ultimately what we strive for, whether by prejudice or dogma, is of paramount importance. We are, for Chesterton, shaped by what we pay attention to.

Nevertheless, while the above narratives provide some insight into Chesterton's novelistic construction of mimetic desire, they only provide a small window onto the role that humility and joy play in creating a space of positive reciprocity. A clearer account of the role that these play in undermining reciprocal violence can be found in Chesterton's novel Manalive (1912), which tells the story of a character named Innocent Smith. Towards the beginning of the novel, Smith arrives at a boarding establishment named Beacon House accompanied by a great wind. ${ }^{72}$ Apart from the obvious symbolism that connects the wind to the Spirit of God, there is the suggestion that Smith breathes new life into the household with his games and general tomfoolery. One of his antics involves setting up the independence of Beacon House, as well as the "High Court of Beacon" - a courtroom that operates independently from the courtrooms of England. ${ }^{73}$ However, just when all seems right with the world, two doctors appear to lay a number of very serious charges against Smith. He is accused of a whole range of crimes: burglary, damage of private property, attempted murder, desertion of spouse, adultery and polygamy. Despite Smith's humble, childlike demeanor, his guilt seems impossible to contest. Nevertheless, before Smith can be taken to a prison or asylum, Michael Moon, whom Smith had recently helped in a personal matter, declares that Smith's case falls under the jurisdiction of the High Court of Beacon. ${ }^{74}$ Accordingly, here we have an indication of Moon's desire to repay Smith's kindness, as well as a traditional means by which mimetic violence is curbed: the judicial system. ${ }^{75}$ Chesterton uses this dramatic device to point to the fact that Innocent Smith may be the Christ figure of this story, since it is the very same judicial setup that was seemingly instigated by Smith that must be the means by which he is held accountable. Moreover, Smith conveys a Christlike subversion of judicial violence by being completely disinterested in the entire legal process, thereby resisting his role as a scapegoat: "He had been provided with pens and paper, out of the latter of which he made paper boats, paper darts, and paper dolls contentedly through the whole proceedings. He never looked up, but seemed as unconscious as a child on the floor of an empty nursery."76 Smith's silence becomes a symbol of the hiddenness of the ideal. ${ }^{77}$ 
As we follow the trial of Innocent Smith, we discover that it is within the confines of certain makeshift legalities that he is shown to be truly innocent. As it turns out, the property that he has damaged and burgled was his own, and his crimes of desertion of spouse, adultery and polygamy can all be explained by the fact that Smith's own wife, Mary Gray, has the habit of wearing different wigs to impersonate other lovers to whom Smith can then freely propose marriage. The true adventure, for Smith, is in Catholic monogamy and fidelity. Even what appeared to have been an attempted murder turns out to be the result of his deliberate aim to miss, for Innocent Smith is a "specially good shot" who willfully misses four or five times at very close range. ${ }^{78}$ Chesterton therefore allows Smith to break conventions without ever once violating the law. All of this, including Smith's unending devotion to his wife, is placed in the context of humility and joy, both of which allow Smith to revel in the alterity and uniqueness of the things that he encounters in the world. Arguably, Moon's best defense of Innocent Smith is found when he explains that Smith is "a plain, practical man: a man of affairs; a man of facts and daylight." 79 Furthermore, Moon tells us that Smith helped him to recognise this world of facts and daylight: "We have wandered into a world of facts ... That grass growing, and that sun going down, and that cab at the door, are facts." ${ }^{\prime 0}$ Consequently, by imitating Smith's humble, joyful ideal of celebration, Moon is given the freedom to defend both similarity and difference; he finds himself both connected to a separate from the world that he is living in. He is able to imitate Smith's ideals without giving into the metaphysical desire to be Smith, and is therefore given over to the positive reciprocity that allows him to fight for Smith to be Smith — someone who is truly innocent. Thus, in Manalive, mimetic desire can be closely connected with positive reciprocity, but only when the ideal that is imitated is humble, joyful and loving.

In the above argument, I have set out to demonstrate that Chesterton and Girard share an important ideal, namely the hope that people will become more aware, not only of what their ideals are, but also of how they arrived at those ideals via any particular intermediary. For both of these intellectual giants, the truth is in the subtext, hidden in plain sight in what Chesterton calls the symbolism of syntax; and, for both, resisting the pull of violent reciprocity and shifting to positive reciprocity takes an act of deliberate, humble resistance. It is Chesterton in particular, however, who argues for joy as the definite medium of this subversion. Joy allows for a selfgiving generosity that seeks to ensure that the unique otherness of the other is both celebrated and sustained. In other words, it is joy that brings the humbled subject to recognize once again that "praise should be the permanent pulsation of the soul."

1. Gilbert Keith Chesterton, Collected works, Volume 1: Heretics, Orthodoxy, The Blatchford controversies [henceforth $C W$ 1], (San Francisco: Ignatius, 1986), 327-328, Emphasis added. 
2. Quoted by Scott Cowdell, "René Girard, modernity and apocalypse," Violence, desire and the sacred, ed. Scott Cowdell, Chris Fleming, \& Joel Hodge, (London: Continuum, 2012), 3; See René Girard, Violence and the sacred, trans. Patrick Gregory, (London: Continuum, 2005), 155.

3. See GK Chesterton, The Napoleon of Notting Hill, (London: John Lane, 1904), 106.

4. See William Johnson, "From the editor," in Contagion: Journal of Violence, Mimesis, and Culture 18, no. 1 (2011), v.

5. GK Chesterton, Collected works, volume 36: The Illustrated London News 1932-1934 [henceforth CW 30], (San Francisco: Ignatius, 2011), 63.

6. GK Chesterton, Collected works, Volume 20: Christendom in Dublin, Irish Impressions, The New Jerusalem, $A$ short history of England [henceforth CW 20], (San Francisco: Ignatius, 2001), 584; GK Chesterton, Collected works, Volume 5: The outline of sanity, The end of the Armistice, Utopia of usurers, and others, (San Francisco: Ignatius, 1987), 479.

7. GK Chesterton, Autobiography, (San Franscisco: Ignatius, 2006), 318.

8. GK Chesterton, Manalive, (London: Dover, 2000), 40.

9. GK Chesterton, Collected works, Volume 34: The Illustrated London News [henceforth CW 34],

(San Franscisco: Ignatius, 1991): 90, 114, 118; GK Chesterton, A miscellany of men, (London:

Dodd \& Mead, 1912), 239; GK Chesterton, Alarms and discursions, (London: Dodo Press, 2008), 22.

10. Chesterton, $C W$ 11, 313; GK Chesterton, $C W$ 20, 584; Chesterton, $C W$ 34, 518-519; GK

Chesterton, The everlasting man, (San Franscisco: Ignatius, 1993), 87.

11. Chesterton, $C W 1,310$.

12. GK Chesterton, What's wrong with the world, (San Franscisco: Ignatius, 1994), 27.

13. GK Chesterton, The everlasting man, (San Franscisco: Ignatius, 1993), 129.

14. GK Chesterton, Saint Thomas Aquinas, Saint Francis of Assisi [henceforth ST], (San Francisco: Ignatius, 2002), 32.

15. See 1 Corinthians 11:1 and 2 Thessalonians 3:7-9.

16. Girard, The Girard reader [henceforth GR], ed. James G Williams, (New York: Crossroad Publishing Company, 1996), 48-49, 289; Girard, Deceit, desire and the novel [henceforth DD\&N], trans. Yvonne Freccero, (Baltimore: Johns Hopkins University Press, 1966), 55, 83.

17. Chesterton, ST, 283, Emphasis added.

18. Chesterton, The everlasting man [henceforth EM], 103.

19. Chesterton, EM, 197.

20. Chesterton, EM, 197.

21. Girard, GR, 61.

22. James Alison, “Girard's breakthrough,” April 24, 2013, bttp:// wnw.jamesalison.co.uk/texts/eng05.html

23. Chesterton, EM, 103. 
24. See James George Frazer, The Golden Bough: A study of magic and religion, (New York: Macmillan, 1922).

25. Chesterton, EM, 103.

26. Chesterton, EM, 111, 113, 175.

27. Chesterton, EM, 112.

28. Wolfgang Palaver, René Girard's mimetic theory [henceforth RGMT], trans. Gabriel Borrud, (East Lansing: Michigan State University Press, 2013), 27.

29. Girard, DD\&N, 63.

30. Girard, GR, 282; Palaver, RGMT, 83.

31. Palaver, RGMT, 86; Chesterton, ST, 158.

32. Chesterton, $S T, 155$.

33. Palaver, RGMT, 86; Girard, DD\&N, 65.

34. Palaver, RGMT, 87.

35. Girard, DD\&N, 38.

36. Girard, GR, 68.

37. Girard, DD\&N, 38.

38. Chesterton, TD, 84.

39. SEE MATTHEW 9:9-12, 13:13, 19:30; LUKE 9:24, 48; 14.11; JOHN 9:41.

40. GK Chesterton, The defendant [henceforth TD], (New York: Wildside Press, 2005), 81.

41. Chesterton, TD, 81.

42. Chesterton, TD, 81.

43. Chesterton, $C W 1,234$.

44. Chesterton, $C W 1,364$.

45. Aidan Nichols, G. K. Chesterton, Theologian (Manchester: Second Spring, 2009), 113.

46. GK Chesterton, Collected works, Volume 37: The Illustrated London News 1935-1936, (San

Francisco: Ignatius, 2013), 206.

47. Chesterton, $C W 1,337$.

48. Chesterton, $C W 1,274$.

49. GK Chesterton, Father Brown: Selected stories, (London: Collector's Library, 2003), 13.

50. Chesterton, Father Brown: Selected stories [henceforth FB], 15.

51. Chesterton, FB, 15.

52. Chesterton, $F B, 16$.

53. Chesterton, $F B, 18$.

54. Chesterton, FB, 18.

55. Chesterton, $F B, 19$.

56. Chesterton, $F B, 22$.

57. Chesterton, FB, 28. 
58. Chesterton, FB, 29.

59. Chesterton, $F B, 33$.

60. Chesterton, FB, 33.

61. Chesterton, $F B, 33$.

62. Chesterton, EM, 217.

63. GK Chesterton, The well and the shallows, (San Franscisco: Ignatius, 2006), 130.

64. GK Chesterton, Tremendous trifles, (London: Dover, 2007), 69; GK Chesterton, The man who was orthodox, ed. Alan Lawson Maycock, (London: Dennis Dobson, 1963), 101.

65. GK Chesterton, The man who was Thursday (London: Atlantic, 2008), 36.

66. Chesterton, The man who was Thursday, 160.

67. Chesterton, $C W 36,42-43$.

68. Chesterton, $C W 36,63$.

69. Chesterton, The man who was orthodox, 98.

70. Chesterton, What's wrong with the world, 23.

71. Chesterton, What's wrong with the world, 23.

72. Chesterton, Manalive, 1.

73. Chesterton, Manalive, 22-23.

74. The personal matter in question is directly related to mimetic desire. When Smith proposes to Mary Gray, Michael Moon decides that marriage is an ideal that he wants for himself and thus proposes to Rosamund Hunt. Soon afterwards, the character Arthur Inglewood, who is also in the process of contemplating becoming engaged to Diana Duke, remarks that "health really is catching, like disease". The contagion of "sanity has broken out, and is spreading". See Chesterton, Manalive, 34.

75. Girard, V\&s, 19.

76. Chesterton, Manalive, 56.

77. Smith's lover, Mary Gray, also mirrors this symbolism in that she remains intensely quiet, even while "her silence was a sort of steady applause." See Chesterton, Manalive, 22.

78. Chesterton, Manalive, 64.

79. Chesterton, Manalive, 30.

80. Chesterton, Manalive, 30.

81. Chesterton, $C W 1,364$. 